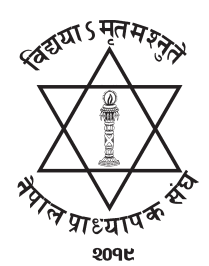

NJ: NUTA

\title{
Preparation and Quality Evalution of Amala (Phyllanthus emblica L.) Fruit Leather
}

\author{
Nabin Guragain ${ }^{1}$ and Yadav KC*2 \\ ${ }^{1}$ Dharan Multiple Campus Tribhuvan University, Nepal \\ ${ }^{2}$ Central Campus of Technology, Tribhuvan University, Nepal \\ * Corresponding author Email: ykcdng504@gmail.com
}

\begin{abstract}
Preparation and quality evaluation of amala (Phyllanthus emblica L.) fruit leather from chakaiya variety was done. The amala pulp and sugar were mixed separately at the proportion of 50:50, $65: 35,57.5: 42.5,80: 20$, and 72.5:27.5 to prepare leather and labeled as samples $A, B, C, D$ and E respectively. Total soluble solids, acidity, $p H$, total ash, crude protein, crude fat, crude fiber, total sugar and vitamin $C$ content of each product samples prepared were determined. For sensory analysis, 9-point hedonic rating test was carried out. Sensory evaluation showed that all the sensory attribute scores were significantly higher $(P<0.05)$ in leather prepared by using 65 parts and 57.5 parts amala pulp. The chemical analysis of leather samples showed that crude fat $(0.26 \pm 0.02 \%)$, crude protein $(1.60 \pm 0.06 \%)$, crude fiber (4.78 $\pm 0.06 \%)$, total ash $(2.29 \pm 0.04 \%)$, acidity $(2.60 \pm 0.01 \%)$ and vitamin $C(394.37 \pm 0.6 \mathrm{mg} / 100 \mathrm{~g})$ were significantly higher $(P<0.05)$ in leather prepared by using amala pulp: sugar ratio of 80:20. But, total soluble solids $\left(67 \pm 0.5^{\circ} \mathrm{Bx}\right)$, energy value $(382.60 \pm 0.95 \mathrm{Kcal} / 100 \mathrm{~g})$ and total sugar (88.82 $\pm 1.12 \%$ ) were significantly higher in leather prepared by using 50 parts amala pulp. However, nutritional characteristics in sample B (65 parts pulp) were significantly higher than that of sample C (57.5 part pulp) so that sample B was selected as the best of all the samples.
\end{abstract}

Key words: Amala pulp, chemical analysis, leather, nutritional analysis, sensorial properties

\section{Introduction}

Amala (Phyllanthus emblica L.) is indigenous to tropic and subtropical areas of Nepal and Southeast Asia. It has been traditionally used in the 'Ayurvedic' and 'Unani' systems of medicine since time immemorial (Gopalan, Ramasastri, \& Bal Subramanian, 1993; Shah, 1978). It is highly nutritious and one of the richest source of ascorbic acid. This fruit is extensively used in the preparation of ayurvedic medicines (Ranote, 2006). Dehydrated form of amala (normally powder) is generally used in different ayurvedic preparations. Dehydrated products have longer shelf life and can be used in the off season of the particular fruit crop (Ranote, 2006). Amala is highly nutritious and could be an important dietary source of vitamin $\mathrm{C}$, minerals and amino acids. More than 50 processed products are prepared from amala fruits to exploit nutrition and medicinal qualities (Mitra \& Pathak, 2008). Amala is used for preparing fruit leather, pickles and dry-candy (salt and spiced titaura) in homes. 
Amala preserve (mada or murabba) is a delicious product which is liked by many people in India and Nepal (Shah, 1978). Fruit leathers are dried sheets of fruit pulp that have a soft, rubbery texture and a sweet taste. The edible portion of fruit is pulped, pureed, mixed with different ingredients to improve its physicochemical and sensory characteristics. These are then heated, formed and dried on flat trays until cohesive fruit leather is obtained. Fruit leather can be eaten as snack foods or added to a variety of food preparation (Raab \& Oehler, 1999). A large numbers of fruit leathers such as mango leather, apricot fruit leather, grape leather, papaya leather etc are discussed (Natalia, Ruiz, Demarchi, \& Giner, 2011). There are no advanced technologies for fruit processing in Nepal. Fruit leather, also known as "mada"; is a traditional food of Nepal. This study can be beneficial in the advancement towards scientific modification of the traditional product. Very few studies have been done on the quality losses during its processing. Hence, this study is concerned in developing the nutritional and sensorial rich amala leather.

\section{Materials and methods}

\section{Collection of raw materials}

Amala (Phyllanthus emblica L.) fruit of chakaiya variety and sugar was obtained from the market of Dharan, Nepal.

\section{Preparation of Leather}

Leather was prepared as described by many researchers (Kumar, Patil, \& Mondal, 2010) with some modification as per the taste and practices of local people. Fresh matured amala fruits were washed with potable water to remove dirt and other foreign matter. Seeds were removed manually by knives. They were boiled at $100^{\circ} \mathrm{C}$ for $10 \mathrm{~min}$ addition (KC, Rayamajhi, Dangal, \& Shiwakoti, 2020) to soften its texture. They were blended in grinder for few min until fine paste was obtained. Amala pulp (50-80 parts) and sugar content (20-50 parts) were mixed uniformly in different proportions to prepare its leather. Its pulp was varied at the equal interval of fruit content 7.5 parts to get five samples as shown in table 1 . Pectin content of $0.8 \%$ was added in all the preparations for the stable texture of the product. Experimental trials were conducted where pulp content less than $50 \%$ resulted loss in aroma and taste where more than $80 \%$ resulted more astringent taste, unacceptable for consumption by majority of panelist. Pectin content $0.2-1 \%$ was added for leather preparation where $0.8 \%$ was found to stabilize the texture. The mixture was spread uniformly on stainless steel tray. Glycerol was used for easy scrapping of the leather after drying. Drying process was performed in cabinet drier. Drying process was carried in a controlled temperature of $55 \pm 5^{\circ} \mathrm{C}$ for 24 hours to obtain moisture content of $15 \pm 1 \%$. After 12 hours, leather was scraped and inverted for uniform and complete drying. The dried fruit leather were cut into uniform square shapes (approx. $2.5 \mathrm{~cm} \times 2.5 \mathrm{~cm}$ ) using a sharp knife. Low Density Poly-ethylene (LDPE) plastic was used for packing final product. They were labelled and stored in a cool and dry place.

\section{Proximate and chemical analysis}

Proximate analysis of raw materials was carried out in triplicate. Standard methods of analysis by Association of Official Analytical Chemists (AOAC) were used: (AOAC 935.29) for moisture content, (AOAC 922.06) for crude fat, (AOAC 992.23) for crude protein, (AOAC 923.03) for total ash and (AOAC 962.09) for crude fiber were used (AOAC, 2005). Total carbohydrate in all raw materials 
was calculated by deducting predetermined values of moisture, crude fat, crude protein and total ash from 100 as given in equation 1 . The energy values were calculated by multiplying the values of crude proteins, lipids, and carbohydrates by recommended factors (4, 9, and 4, respectively). The energy values were expressed as Kcal/100 g (Kc, Rai, et al., 2020). Ascorbic acid (vitamin C) was determined by 2,6-dichlorophenol indophenol visual dye method. Total soluble solids (TSS) of the amala pulp and its leather were determined by using hand refractometer (AviChem Industries, India). For the determination of $\mathrm{pH}$, digital $\mathrm{pH}$ meter ( \pm 0.1 units, Hanna, Mauritius) was used. Acidity was determined by titrimetric method and total sugar was determined by using Fehling's solutions (Ranganna, 1986).

Total carbohydrate $(\%)=[100-(\%$ moisture $+\%$ total ash $+\%$ crude protein $+\%$ crude fat $+\%$ crude fiber)]---------------equation 1.

Table 1 Samples with different proportion of amala pulp and sugar

\begin{tabular}{llll}
\hline Samples & Amala Pulp (parts) & Sugar (parts) & Pectin (\%) \\
\hline A & 50 & 50 & 0.8 \\
B & 65 & 35 & 0.8 \\
C & 57.5 & 42 & 0.8 \\
D & 80 & 20 & 0.8 \\
E & 72.5 & 27.5 & 0.8 \\
\hline
\end{tabular}

\section{Sensory evaluation}

Twenty panelists of 20-35 years with sound health were trained before evaluating the samples of amala leather by using 9-point hedonic rating test (Ranganna, 1986). A $2 \mathrm{~h}$ training session was conducted for 4 days to familiarize panel members with sensory attributes and sensory evaluation was conducted between 1:00 PM to 2:00 PM. The panelists were provided with the uniform quantity of leather in stainless steel plate to analyze appearance, flavor, texture and overall acceptability.

\section{Statistical analysis}

The data of each experimental analysis that were performed in triplicate was analyzed by oneway analysis of variance (ANOVA) by using software GenStat Release 12.1 (Copyright 2009, VSN International Ltd.). Means were compared using Tukey's HSD post hoc test $(\mathrm{P}<0.05)$.

\section{Results and discussion}

Nutritional and Chemical analysis Moisture content of the amala was similar to the findings of (Parveen \& Khatkar, 2015). Total ash, crude protein, crude fiber and carbohydrate of the amala (Table 2) were similar to the findings of (Iwansyah et al., 2020) but in the study of (Parveen \& Khatkar, 2015) crude fiber was found higher. Some of the parameters were similar and some were different when compared to the different researches (Khattak, 2013). The pH and TSS were similar to the findings of (Kulkarani, Pandey, Sharma, \& Joshi, 2017; Ranote, Hothe, \& Bawa, 2002). Vitamin C content of $578.3 \pm 0.05 \mathrm{mg}$ ascorbic acid $/ 100 \mathrm{~g}$ was reported in raw amala (table 3 ). Amala fruit is one of the richest sources of ascorbic acid (445-468 mg /100 g) and has many phenolic compounds, but the sour and astringent taste makes the fresh amala fruit less acceptable to consumers (Nadheesha, Bamunuarachchi, Edirisinghe, \& Weerasinghe, 2011). The variation of the nutritional and chemical constituents might be due to varietal difference, variation of agronomic practices, climate, and geography and soil conditions. 
The mean vitamin C content of samples A, B, C, D and E is presented in table 4. The vitamin $\mathrm{C}$ varied in the amala leather samples as per the proportion of amala pulp addition (KC, Rayamajhi, et al., 2020). The loss in vitamin $\mathrm{C}$ was due to various factors such as heat processing, oxidation, light. The loss in vitamin C content was also seen in drying of amala (Prajapati, Nema, \& Rathore, 2011). Higher the sugar in samples, higher will be the TSS. Acidity increases with the addition of pulp (KC, Rayamajhi, et al., 2020) which is due to higher acid content in raw pulp. Crude fat, crude protein, crude fiber, total ash, moisture and energy content of the different amala leather samples varied significantly $(\mathrm{p}<0.05)$ and found to be in the range of $0.16-0.26 \%, 0.82-1.6 \%, 3.04-4.78 \%, 1.50-2.29 \%, 15.50$ $15.72 \%$ and $373.01-382.60 \mathrm{Kcal} / 100 \mathrm{~g}$ respectively (Table 5). The content of proximate components was reported according to the proportion of amala pulp addition (KC, Rayamajhi, Dangal, \& Shiwakoti, 2020). The slight changes were observed which might be due to effect of processing conditions. Higher amount of sugar might have caused dehydration effecting resulting in the moisture reduction (Chen, Liu, \& Chen, 2002). Energy value of sample A (leather with 50 part amala pulp) was found higher than others which might be due to contribution of higher amount of sugar (Clemens et al., 2016).

Table 2 Nutritional analysis of amala fruit

\begin{tabular}{ll}
\hline Chemical composition & Values \\
\hline Moisture (\%) & $83.20 \pm 0.2$ \\
Total Ash (\%) & $2.5 \pm 0.2$ \\
Crude Fat (\%) & $0.28 \pm 0.13$ \\
Crude protein (\%) & $1.93 \pm 0.2$ \\
Crude fiber (\%) & $5.30 \pm 0.35$ \\
Total Carbohydrate (\%) & $6.79 \pm 1.21$ \\
Total Energy (Kcal/ $100 \mathrm{~g})$ & $37.40 \pm 7.5$ \\
\hline
\end{tabular}

Values are means of triplicate \pm standard deviation

Table 3 Chemical analysis of amala fruit

\begin{tabular}{ll}
\hline Chemical composition & Values \\
\hline Acidity (\% citric acid) & $2.70 \pm 0.02$ \\
pH & $3.5 \pm 0.15$ \\
TSS $\left({ }^{\circ} \mathrm{Bx}\right)$ & $11.50 \pm 0.03$ \\
Ascorbic acid $(\mathrm{mg} / 100 \mathrm{~g})$ & $578.3 \pm 0.05$ \\
Reducing sugar $(\%)$ & $3.10 \pm 0.02$ \\
Non reducing sugar $(\%)$ & $4.62 \pm 0.21$ \\
Total sugar $(\%)$ & $7.72 \pm 0.68$ \\
\hline
\end{tabular}

Values are means of triplicate \pm standard deviation

Table 4 Chemical analysis of different samples of amala leather

\begin{tabular}{lllll}
\hline Samples & $\begin{array}{l}\text { Vitamin } \\
(\mathbf{m g} / \mathbf{1 0 0} \mathbf{g} \mathbf{~ D m})\end{array}$ & $\mathbf{C}$ TSS $\left({ }^{\circ} \mathbf{B x}\right)$ & Acidity $(\mathbf{d b} \%)$ & Total Sugar $(\mathbf{d b} \%)$ \\
\hline $\mathrm{A}$ & $331.59 \pm 2.10^{\mathrm{a}}$ & $67 \pm 0.50^{\mathrm{c}}$ & $1.68 \pm 0.01^{\mathrm{a}}$ & $88.82 \pm 1.12^{\mathrm{e}}$ \\
$\mathrm{B}$ & $361.53 \pm 0.36^{\mathrm{c}}$ & $61.5 \pm 0.1^{\mathrm{b}}$ & $2.15 \pm 0.03^{\mathrm{c}}$ & $64.52 \pm 0.92^{\mathrm{c}}$ \\
$\mathrm{C}$ & $341.11 \pm 2.55^{\mathrm{b}}$ & $64.0 \pm 0.5^{\mathrm{bc}}$ & $1.91 \pm 0.02^{\mathrm{b}}$ & $75.05 \pm 0.21^{\mathrm{d}}$ \\
$\mathrm{D}$ & $394.37 \pm 0.60^{\mathrm{e}}$ & $50.0 \pm 3.0^{\mathrm{a}}$ & $2.60 \pm 0.01^{\mathrm{e}}$ & $37.06 \pm 2.08^{\mathrm{a}}$ \\
$\mathrm{E}$ & $386.60 \pm 1.10^{\mathrm{d}}$ & $54.0 \pm 2.0^{\mathrm{a}}$ & $2.41 \pm 0.01^{\mathrm{d}}$ & $47.25 \pm 1.47^{\mathrm{b}}$ \\
\hline
\end{tabular}

Values are means of triplicate \pm standard deviations. Values in the columns bearing the different superscripts are significantly different $(\mathrm{P}<0.05)$ 
Table 5 Nutritional analysis of different samples of amala leather

\begin{tabular}{|c|c|c|c|c|c|c|c|}
\hline Samples & $\begin{array}{l}\text { Moisture } \\
\text { content (wb } \\
\% \text { ) } \\
\end{array}$ & $\begin{array}{l}\text { Crude fat } \\
\text { (db \%) }\end{array}$ & $\begin{array}{l}\text { Crude } \\
\text { protein (db } \\
\%)\end{array}$ & $\begin{array}{l}\text { Crude } \\
\text { fiber (db } \\
\%)\end{array}$ & $\begin{array}{l}\text { Total ash } \\
\text { (db \%) }\end{array}$ & $\begin{array}{l}\text { Carbohydrate } \\
\text { (db \%) }\end{array}$ & $\begin{array}{l}\text { Energy } \\
\text { (Kcal/100 g } \\
\text { Dm) }\end{array}$ \\
\hline A & $15.50 \pm 0.03^{\mathrm{a}}$ & $0.16 \pm 0.01^{\mathrm{a}}$ & $0.82 \pm 0.21^{\mathrm{a}}$ & $3.04 \pm 0.12^{\mathrm{a}}$ & $1.50 \pm 0.13^{\mathrm{a}}$ & $94.48 \pm 0.47^{\mathrm{c}}$ & $382.60 \pm 0.95^{\mathrm{e}}$ \\
\hline B & $15.57 \pm 0.10^{\mathrm{a}}$ & $0.22 \pm 0.02^{\mathrm{bc}}$ & $0.98 \pm 0.01^{\mathrm{a}}$ & $4.05 \pm 0.17^{\mathrm{c}}$ & $1.89 \pm 0.10^{\mathrm{b}}$ & $92.86 \pm 0.30^{\mathrm{b}}$ & $377.30 \pm 0.98^{c}$ \\
\hline $\mathrm{C}$ & $15.53 \pm 0.01^{\mathrm{a}}$ & $0.19 \pm 0.03^{\mathrm{ab}}$ & $0.91 \pm 0.12^{\mathrm{a}}$ & $3.48 \pm 0.05^{\mathrm{b}}$ & $1.67 \pm 0.02^{\mathrm{a}}$ & $93.75 \pm 0.22^{\mathrm{c}}$ & $380.40 \pm 0.13^{\mathrm{d}}$ \\
\hline $\mathrm{D}$ & $15.72 \pm 0.01^{\mathrm{b}}$ & $0.26 \pm 0.02^{\mathrm{c}}$ & $1.60 \pm 0.06^{\mathrm{b}}$ & $4.78 \pm 0.06^{\mathrm{e}}$ & $2.29 \pm 0.04^{\mathrm{c}}$ & $91.07 \pm 0.18^{\mathrm{a}}$ & $373.01 \pm 0.30^{\mathrm{a}}$ \\
\hline E & $15.63 \pm 0.01^{\mathrm{ab}}$ & $0.24 \pm 0.01^{\mathrm{bc}}$ & $1.42 \pm 0.20^{\mathrm{b}}$ & $4.37 \pm 0.03^{\mathrm{d}}$ & $2.14 \pm 0.03^{\mathrm{c}}$ & $91.83 \pm 0.13^{\mathrm{a}}$ & $375.02 \pm 0.19^{b}$ \\
\hline
\end{tabular}

Values are means of triplicate \pm standard deviations. Values in the columns bearing the different superscripts are significantly different $(P<0.05)$. Here, wb refers wet basis, $d b$ refers dry basis and Dm refers dry matter.

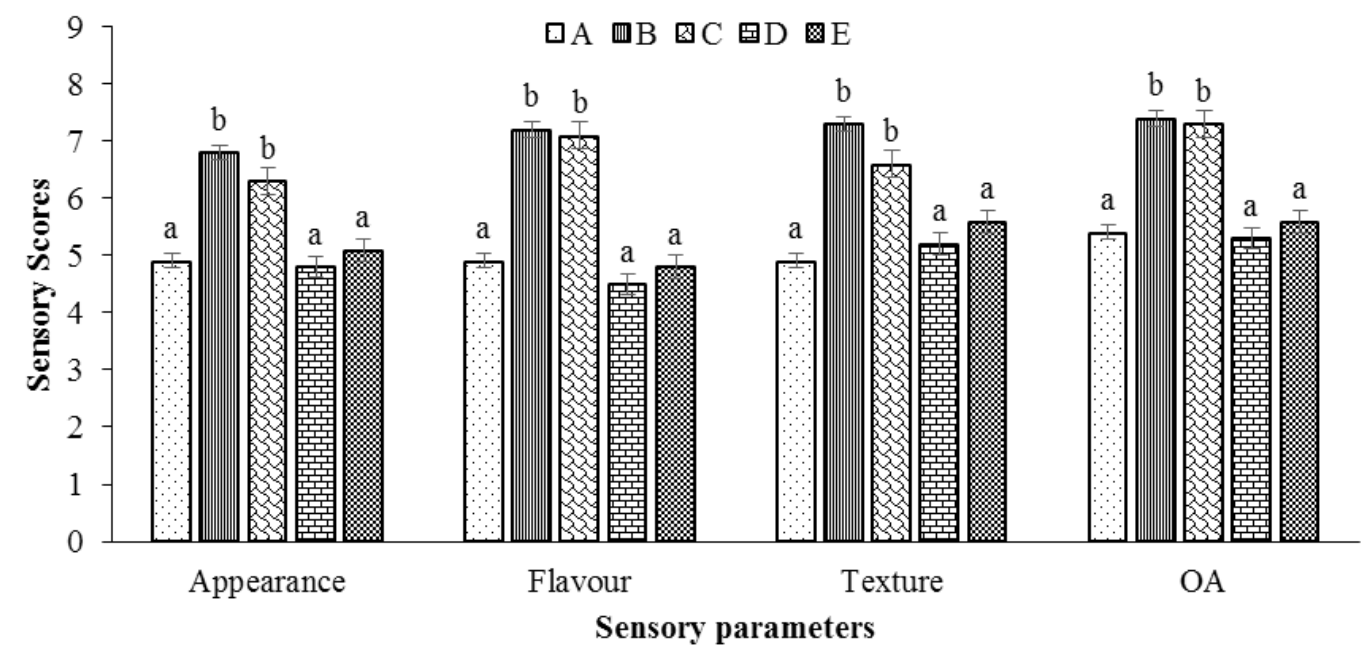

Fig. 1 Sensory analysis of the different samples of leather. Error bars show standard deviation and error bars bearing difference superscript differs significantly $(\mathrm{P}<0.05)$

Sensory analysis of leather

Sensory parameters appearance, flavor, texture and overall acceptability of the samples B and C of leathers varied significantly with samples A, D and E (Fig. 1). Leather with higher part of amala (sample D) was not liked by many panelists. Astringent and acidic flavor in sample D might be due to more amala pulp. Amala has astringent and acidic taste and flavor naturally (Sachan, Gangwar, Sharma, \& Kumar, 2013). Overall acceptability (OA) of samples B and C were significantly higher than other samples (Fig. 1). Sample B (leather with 65 parts pulp and 35 parts sugar) and sample C (leather with 57.5 parts pulp and 42.5 parts sugar) were found superior in sensory characteristics. This might be due to the balance of sugar and pulp where extreme astringency and sourness were masked. The sensory evaluation, here found that the desirable characteristics, smooth brownish white appearance, pleasant 
aroma and desirable sweet taste, soft and leathery texture and overall acceptability were higher in samples B and C, suggesting that $65: 35$ and 57.5:42.5 proportion of pulp and sugar was more desirable in leather preparation.

\section{Selection of the best product}

The selection of best product was on the basis of sensory scores and nutritional characteristics. High sensory scored samples were compared on the basis of nutritional characteristics to obtain best product The sensory scores of sample B and $\mathrm{C}$ were similar and highest among all the samples but the nutritional characteristics in Sample B was significantly higher $(\mathrm{P}<0.05)$ than that of sample $\mathrm{C}$ so that sample B was selected as the best of all the samples. Nutritional characteristics in the sample D (leather prepared from 80:20 proportions of pulp and sugar) had significantly higher nutritional values but it had lower sensory score.

\section{Conclusions}

Generally, amala is seasonal fruit and are highly perishable and hence they need to be preserved. It is astringent and sour, making it less acceptable to consume it as raw fruit. Its leather increases the sensorial acceptability of and its market value. Its leather is a dehydrated product and its self-life is also long as compared to fresh fruit. Amala leather can be prepared by varying the parts of pulp and sugar. Though the leather with more pulp was higher in nutritional content, it is suggested to use 65:35 proportions of pulp and sugar in leather preparation for higher consumer acceptance.

Conflicts of interest

The authors declare no conflicts of interest.

\section{Acknowledgements}

We thank to Prof. Dr. Dhan Bahadur Karki for his useful suggestions in this research work.

\section{References}

AOAC. (2005). Official Methods of Analysis (18th ed.). Suite 500481 North Frederick Avenue Gaitherwsburg, Maryland 20877-2417, USA: Association of Official Analytical Chemists.

Chen, W., Liu, D., \& Chen, M. (2002). Effects of high level of sucrose on the moisture content, water activity, protein denaturation and sensory properties in Chinese-style pork jerky. 15(5), 85-90.

Clemens, R. A., Jones, J. M., Kern, M., Lee, S. Y., Mayhew, E. J., Slavin, J. L., \& Zivanovic, S. (2016). Functionality of sugars in foods and health. 15(4), 33-70.

Gopalan, C. I., Ramasastri, B. V., \& Bal Subramanian, S. C. (1993). Nutritive value of Indian foods. 6, 17-18.

Iwansyah, A., Surahman, D., Hidayat, D., Luthfiyanti, R., Indriati, A., \& Ardiansyah, C. (2020). Comparative evaluation of proximate composition and vitamin $\mathrm{C}$ of Physalis angulata Linn and Physalis peruviana Linn in West Java, Indonesia. E\&ES, 462(1), 012012.

Kc, Y., Rai, R., Katuwal, N., Shiwakoti, L. D., Pant, B. R., Bajgai, T. R., . . . Upadhyaya, J. (2020). Phytochemicals, nutritional, antioxidant activity, and sensory analyses of Moringa oleifera Lam. collected from mid-hill region of Nepal. Nat Prod Res, 1-4. doi:10.1080/14786419.20 20.1781113 .

KC, Y., Rayamajhi, S., Dangal, A., \& Shiwakoti, D. L. (2020). Phytochemical, Nutritional, Antioxidant Activity and Sensorial Characteristics of Amala (Phyllanthus emblica L.) Chutney. 18(1), 43- 
52.

Khattak, K. (2013). Proximate composition, phytochemical profile and free radical scavenging activity of radiation processed Emblica officinalis. International Food Research Journal, 20(3).

Kulkarani, P., Pandey, H., Sharma, A., \& Joshi, D. (2017). Physicochemical properties of aonla fruit and juice. Chem Sci Rev Lett, 6, 1343-1347.

Kumar, R., Patil, R. T., \& Mondal, G. (2010). Development and evaluation of blended papaya leather. 565-570.

Mitra, S. K., \& Pathak, P. K. (2008). Aonla (Emblica officinalis Gaertn.)—a unique fruit tree with rich nutritional and medicinal properties.

Nadheesha, M., Bamunuarachchi, A., Edirisinghe, E., \& Weerasinghe, W. (2011). Studies on antioxidant activity of Indian gooseberry fruit and seed. Journal of Science of the University of Kelaniya Sri Lanka, 3.

Natalia, A., Ruiz, Q., Demarchi, S., \& Giner, S. (2011). Research on dehydrated fruit leathers: A Review. Journal of Food Sci. Technol, 41(6), 684-686.

Parveen, K., \& Khatkar, B. (2015). Physico-chemical properties and nutritional composition of aonla (Emblica officinalis) varieties. International Food Research Journal, 22(6), 2358.

Prajapati, V., Nema, P. K., \& Rathore, S. (2011). Effect of pretreatment and drying methods on quality of value-added dried aonla (Emblica officinalis Gaertn) shreds. Journal of food science and technology, 48(1), 45-52.

Raab, C., \& Oehler, N. (1999). Making dried fruit leather-Fact Sheet, Lane County. 23, 337-343.

Ranganna, S. (1986). Handbook of analysis and quality control for fruit and vegetable products: Tata McGraw-Hill Education.

Ranote, P., Hothe, R., \& Bawa, A. (2002). Preparation, evaluation and storage of preserve made from Amla cultivars grown in Kandi area of Punjab State.

Ranote, P. S. (2006). Value added Aonla Product. 20(2), 113-118.

Sachan, N., Gangwar, S., Sharma, R., \& Kumar, Y. (2013). An Investigation into Phytochemical Profile and Nutraceutical Value of Amla (Emblica officinalis) Fruits. International Journal of Modern Pharmaceutical Research [ISSN 2319 5878], 02, 01-12.

Shah, D. H. (1978). Chemical composition of Amla. Research Bulletin of Food Agr. and irrigation Ministry food research seaction. 